\title{
IMPACTOS DA TRADUÇÃO ESCRITA NO BRASIL DO SÉCULO XIX
}

\author{
Dennys da Silva Reis
}

\section{Introdução}

Havendo apresentado este artigo primeiramente como um ensaio menor no III Encontro de História do Império Brasileiro - Cultura e Poder no Oitocentos em 2012 e, logo após, somente parte dele no XI Congresso Internacional da ABRAPT e V Congresso Internacional de Tradutores em 2013; e somado a isso o fato de que a pesquisa em História da Tradução é sempre contínua, as páginas agora descritas com maior densidade tentam esboçar de maneira panorâmica (mas não exaustiva) os impactos da tradução escrita na sociedade brasileira do século XIX, desvendando o véu da história da tradução deste período e contribuindo assim para sua maior visibilidade.

Para este fim, a história do Brasil, a história do livro, a história de editoras foram revisitadas; e os casos de traduções, assim como a biografia de alguns tradutores, foram percorridos. Optamos por não fazer uma ordem cronológica dos fatos a fim de enfatizar os diferentes campos ou esferas da tradução no Oitocentos e também porque diversos eventos tradutórios ocorriam de maneira simultânea, às vezes com igual importância no âmbito nacional ou com destaque específico para determinadas áreas e domínios da cultura e da sociedade.

Vale lembrar que o conceito de campo adotado para nosso estudo tem base no pensamento de Bakhtin, pois "cada campo de criatividade ideológica tem seu próprio modo de orientação para a realidade e refrata a realidade à sua própria maneira. Cada campo dispõe de sua própria função no conjunto da vida social. É seu caráter semiótico que coloca todos os fenômenos ideológicos sob a mesma definição geral" (Bakhtin \& Voloshinov, 1992, p. 33). Isto é, o conceito geral que nos propomos estudar é a História da Tradução, porém as diversas ideologias ou repartições desta história nos levam a constatar orientações, funções e elementos ideológicos no que tange à tradução como processo e como produto, mas também ao aludir a seu agente acional inserido em contextos maiores como a sociedade e a cultura. Em consequência disso, podemos falar de tipos de tradução e sua(s) devida(s) história(s). 


\section{Uma visão geral do mercado livreiro}

A vinda da Família Real para o Brasil no século XIX impulsionou a imprensa nacional, desencadeou o "fim" da censura, a importação de costumes europeus (como o hábito de ler e adquirir livros) e também a criação de universidades, contribuindo para a formação de um público leitor e para atenuar as lacunas intelectuais desse público. Exemplo disso foi a vinda da Missão Francesa (1816) ao Brasil que, apoiando-se no processo tradutório, trouxe grandes contribuições e estabeleceu novos paradigmas intelectuais e culturais nas artes em geral. A criação da Escola de Belas Artes pela Missão Francesa singularizou uma nova ferramenta de ensino, que até então não era utilizada no Brasil - os livros, os quais, em sua maioria, eram escritos em francês ou traduzidos para o português.

A criação da Imprensa Régia (13/05/1808) foi concomitante ao fim da proibição de imprimir livros: já se podia então imprimir, divulgar e fazer circular livros na colônia, em português ou traduzidos; mas, ainda assim, a censura permaneceu por mais treze anos. A principal função da Imprensa Régia era a divulgação dos atos oficiais da Corte, mas também era possível a publicação de outros textos como, por exemplo, as traduções. Nessa mesma época surgiram as primeiras tipografias no Rio de Janeiro, na Bahia e em Pernambuco, que publicavam os livros que não eram censurados; os romances célebres e sentimentais, morais ou tristes, dos quais os editores suprimiam o nome do autor e acrescentavam títulos sugestivos e tentadores para induzir a compra (Wyler, 2003).

A censura foi suprimida em 28/08/1821, medida que descortinou novos rumos para leitores, livreiros, importadores, impressores e tradutores. Com isso, multiplicaram-se as tipografias, livrarias e tradutores. A primeira tipografia após a Impressa Régia foi a Silva Serva, responsável por traduzir livros de boa qualidade e em vários domínios do campo do saber e do prazer. Outra que se destacou foi a Baptiste Louis Garnier, que desenvolveu um amplo programa de traduções. Garnier, livreiro francês que morava no Rio de Janeiro, contratou muitos tradutores para traduzir obras, sobretudo de autores franceses. Essas traduções eram impressas na França, devido ao elevado preço do papel no Brasil. Alguns fatores contribuíram para o sucesso de seu programa, como o advento do navio a vapor (diminuindo o tempo de viagem entre Paris e o Rio de Janeiro para 22 dias), a ampliação do mercado consumidor, com a abertura de novas rotas em todo o país, e o baixo custo dos livros importados. Não se pode deixar de evocar que também entre os anos de 1850 e 1914 o Brasil exportou para 
Portugal um número significativo de obras no campo literário e das ciências sociais e, dentre essas, estão as traduções brasileiras de autores franceses importadas do Brasil e vendidas em Portugal pelo editor Enersto Chardron e a Livraria Bertrand (Palma, 2012).

\section{Tradução técnico-científica}

Muito se traduziu à época, tanto material de teor literário quanto técnicocientífico. A maioria das traduções técnico-científicas era feita a partir do francês, mas também do inglês e do alemão, quando se tratava de assuntos militares, marítimos e médicos. No início do século XIX, temos a Tipografia do Arco do Cego (1799-1801), que tinha como objetivo reunir em livros memórias de novas técnicas e culturas desenvolvidas em países estrangeiros, que pudessem ser úteis ao progresso do Brasil e da Metrópole. A tipografia, idealizada por José Mariano da Conceição Veloso, produziu centenas de livros traduzidos do francês, inglês, castelhano, alemão e latim, concernentes aos mais diversos assuntos. Pretendia ensinar e informar sobretudo os agricultores brasileiros. O reconhecimento do trabalho da tipografia, cuja existência foi de apenas dois anos, veio somente após sua extinção. Atribui-se comumente o sucesso das províncias de Pernambuco e da Bahia aos conhecimentos transmitidos por muitas dessas traduções.

A tradução com a finalidade de instrução nos mais diversos campos do conhecimento científico não alcançou somente a agricultura, mas perpassava os mais diversos campos das ciências duras. Podemos destacar em particular os médicos ${ }^{1}$ tradutores desta época, que muito contribuíram para o desenvolvimento e ampliação da formação de médicos e da medicina no Brasil, como Pirajá da Silva, tradutor da clássica obra do naturalista alemão Von Martius, Das Naturell, die Krankheiten, das Arztthum und die Heilmittel der Urbewohner Brasiliens (Natureza, doenças, medicina e remédios dos índios brasileiros) e João Francisco da Silva Lima, tradutor do Código de Ethica Médica adoptado pela associação Médica Americana.

A instrução pública foi uma das maiores esferas da tradução técnico-científica em pleno Brasil Império. Inúmeros foram os opúsculos, compêndios didáticos, dicionários, gramáticas, glossários, regimentos, coleções, atlas e tratados traduzidos que beneficiavam desde o nível de ensino mais básico até o nível superior. A carência de

\footnotetext{
${ }^{1}$ Muitos médicos do período oitocentista no Brasil foram tradutores dos mais diversos campos do saber, os citados aqui são apenas aqueles mais conhecidos que traduziram obras importantes e conhecidas do domínio da medicina.
} 
livros destinados especificamente para o ensino era tamanha à época que órgãos responsáveis pela tradução, adaptação e produção autoral dos livros tinham papel fundamental tanto no que compete à censura como na difusão destes livros. Além disso, havia gratificações por parte da lei para traduções feitas com o objetivo educativo, especialmente na instrução pública primária e secundária (Castellanos, 2012). Vale ressaltar que, provavelmente, ao se traduzir tal gênero de literatura técnico-científica no Brasil, esta tenha incentivado e até consolidado este tipo de produção no Brasil devido a dois fatores: o primeiro diz respeito à questão da autoria - o tradutor era considerado, segundo a lei, o autor daquele texto em língua portuguesa; e o segundo no que concerne à estética, ao gênero e ao formato das obras - como não havia modelo para se produzir tais obras no Brasil, a tradução constituiu o espelho para qualquer tipo de livro deste gênero; por exemplo: um compêndio de matemática "traduzido" recebia ao final o nome do tradutor como autor ou coautor porque esta "tradução" era na verdade uma cópiamodelo adaptada ao sistema de ensino brasileiro (Castellanos, 2012).

Percebemos também a existência de bibliotecas especializadas neste período, fruto do desenvolvimento a passos largos da ciência no Brasil. De fato, a Academia Real Militar, a Academia de Guardas Marinhas, o Museu Real, o Jardim Botânico (todos no Rio de Janeiro) e as Academias Médico-Cirurgião (essas no Rio de janeiro e na Bahia), responsáveis pela capacitação de mão-de-obra qualificada, exigiam a difusão de conhecimentos mais elaborados — daí a necessidade da tradução desse tipo obras. Segundo José Carlos de Oliveira (1997, p. 37), todas esses livros

[...] eram manuais a serem usados na Academia Real Militar e na Guarda Marinha, nos cursos de Cirurgia e Medicina e nas preleções avulsas. Esses manuais, na quase totalidade, traduções de obras francesas, onde, não apenas fazia-se a tradução direta, como também compilavam-se os originais, faziam-se alterações e, em vários casos, adicionava-se trechos de outras obras diferentes daquelas que serviram de base para a tradução (sic). Este fato, no entanto, demonstra a necessidade de alguma competência científica para assim proceder. Por isso, pessoas que traduziam as obras não eram meros tradutores: eram professores que adaptavam as obras às necessidades do momento, sabendo realizar cortes e modificações para atingirem os objetivos propostos pelo governo (estampadas nas cartas régias e nos planos de ensino emitidos). A elaboração doméstica de compêndios era um passo em direção à constituição de uma comunidade de homens da ciência. Além disso, as obras escolhidas (como já apontado anteriormente) eram, sobretudo, de autoria de cientistas proeminentes na França. Grande parcela dos compêndios, sob a designação de Elementos ou Tratado elementar, distribuíam-se entre os de Matemática, Física e Medicina - havia ainda os de Astronomia, Mineralogia, Desenho, Botânica, Química, Farmácia e arte militar. [...] 
Tal afirmação é um dos exemplos que mostram o quanto as obras de caráter técnico-científico foram traduzidas no Oitocentos brasileiro, evidenciando, ainda, como era o processo de tradução/adaptação e que tipo de tradutor exercia tal ofício: o tradutor especialista. Dentre os tradutores especialistas responsáveis por inúmeras contribuições a essas bibliotecas especializadas, podemos mencionar os engenheiros militares José Saturnino da Costa Pereira 1773-1852) e Manoel Ferreira de Araújo Guimarães (17771838), ambos matemáticos brasileiros graduados pela Universidade de Coimbra ${ }^{2}$.

Deve-se ressaltar a importância exercida pelo tradutor baiano Caetano Lopes de Moura (1780-1860), também escritor, médico e homem de ciência, que traduziu obras de Walter Scott, Alexandre Dumas, Chateaubriand e diversos textos de referência na área de geografia, história, medicina e filosofia. Lopes de Moura é considerado nosso primeiro tradutor profissional (Paes, 1990), além de ser um dos poucos homens negros a alcançar posição de destaque entre os letrados do Oitocentos ${ }^{3}$. Sua atividade como tradutor era notória, conforme podemos ver no prefácio da tradução (1845) da obra Mês de Maria (1841) da prolífica escritora francesa Tarbé des Sablons:

[C]onfiei a tradução do presente livro ao Doutor Caetano Lopes de Moura (bem conhecido por suas estimáveis traduções), e fiz que a arte tipográfica bem como a gravura pagassem seu tributo à soberana Rainha do mundo, contribuindo tudo a que o perfeito e bem acabado da edição não desdissessem do valioso merecimento da obra. (apud Veiga, 1979, p. 115)

Apesar de todo cuidado que Lopes de Moura tinha com suas traduções, a maioria delas era feita a partir de uma tradução-piloto do francês. Logo, apesar de ele ter estudado alemão e inglês, "é natural que, angustiado pelo volume de traduções a realizar e consequentemente urgência de tempo, recorra, conforme o costume e sua habilitação, a versões francesas" (Veiga, 1979, p. 120). Isso só comprova a hegemonia do francês como língua de cultura à época e a necessidade de tradução de livros dos mais diversos campos para a língua portuguesa, em especial para o Brasil Império em que a circulação de ideias e saberes vindos da Europa era contínua. Todavia, há também as versões - tradução da língua materna para uma língua estrangeira - que também foram realizadas no Oitocentos brasileiro, como revela a notícia abaixo do jornal O Paiz de 8 de outubro de 1884 :

\footnotetext{
${ }^{2}$ A relação completa das traduções realizadas por estes tradutores, dentre outros, pode ser encontrada na tese de doutorado de José Carlos de Oliveira: A cultura científica no Brasil durante o Governo de D. João (1808-1821).

${ }^{3}$ Além de Lopes de Moura, podemos citar outros tradutores negros desta época: Paula Britto, Machado de Assis, Tobias Barreto, Gonçalves Crespo e Lima Barreto.
} 
Da Typographia Nacional acaba de sair um folheto impresso por ordens do governo e que se intitula Guia do Emigrante para o Império do Brasil. [...] o senhor ministro da agricultura ordenara que o Guia do Emigrante fosse vertido para os idiomas francês, alemão e italiano, a fim de ser mais facilmente conhecido nos países europeus. (apud Freitas, 2012)

No que compete ainda à tradução técnico-científica, cabe lembrar que, ao final do século XIX, a popularização do livro, bem como o poder de consumo dos cidadãos, havia aumentado, lançando no mercado livreiro a tendência de venda dos livros da lista de manuais de utilidade prática, que em sua maioria serviam para auxiliar aos leigos em determinadas profissões: Manual Prático do Lavrador, Livro do Criador, Manual do Galinheiro, dentre outros. Estes eram ou traduzidos ou adaptados ao Brasil, sendo de fácil acesso, cotidiano e útil ao seu leitor (El Far, 2004).

\section{Tradução de "ideias subversivas"}

Muitas obras importantes eram traduzidas, ora totalmente, ora parcialmente. Algumas tiveram livre circulação, já outras circularam clandestinamente por conterem ideias subversivas para a época. Atribui-se ao contato com ideias europeias (principalmente francesas), por meio da tradução, muitas das rebeliões abolicionistas, independentistas e republicanas. Além disso, muitos conflitos no Brasil Império se deram graças aos contatos com ideias europeias difundidas no Brasil por intermédio da tradução.

O livro O Papa e o Concílio (1870) do historiador alemão e teólogo Johann Joseph Ignaz von Döllinger, traduzido e prefaciado em português pelo jurisconsulto Rui Barbosa, foi publicado em 1877 sob autoria de Janus e vendido ao preço de oito mil réis (Féder, 2012). A obra é uma tese contra a infalibilidade papal, cuja doutrina foi definida pela Igreja Católica, por ocasião do Concílio Vaticano I, em 1870. Tal obra, no Brasil, foi uma das bases da chamada Questão Religiosa que desgastou bastante a relação entre Estado e Igreja Católica.

A edição desse livro foi toda financiada pelo próprio Rui Barbosa. O notável é que o livro original contém quase 300 páginas e a edição brasileira tem exatamente 608 páginas. De fato, a tradução dessa obra no Brasil é considerada como um grande manifesto a favor da liberdade de expressão e de culto. Ela foi dividida da seguinte forma: prefácio do tradutor, introdução do tradutor e o livro traduzido. No prefácio é explicada a motivação da tradução: 
Ora, a respeito della a nossa Literatura - salva a propaganda, brilhante, infatigavel, admiravel, heroica, mas solitaria, de Ganganelli - é ainda pauperrima, para bem dizer, nulla. No sentido liberal, principalmente, a escassez é ainda mais deploravel. Até agora não possuimos um trabalho methodico, amplo, que irradie luz sobre toda a esphera da questão. Sem presumpção; sem nenhuma confiança a não ser no mais árduo, aprofundado e consciencioso estudo, exercido muitas vezes em mananciaes até agora talvez inteiramente inexplorados entre nós; sem nenhuma ambição mais que a de servir modestamente nossa patria. concorrendo com alguns materiaes irrefugaveis para a instauração da liberdade religiosa, pareceu-nos metter mãos à tentativa.

$[\ldots]$

A Europa olhou-o como o manifesto do catholicismo liberal; governos desse continente houve, que o fizeram traduzir, outros que o distribuiram gratuitamente entre o clero; todos os idiomas cultos, salvo talvez unicamente o portuguez, vernaculisaro-no; e o jesuitismo poz a preço a sua refutação. (Barbosa, 1877, pág. XII)

Já na introdução com mais de 260 páginas, Rui Barbosa explica o que é a Questão Religiosa no Brasil e no mundo, e escreve um verdadeiro manifesto incentivando a separação entre Estado e Igreja e a conscientização pela liberdade individual e coletiva. Com a imensa marca da voz do tradutor no prefácio e especialmente na longa introdução, a tradução do livro em si traz inúmeras notas com o seguinte dizer: "Nota do tradutor brasileiro", o que dá a entender que de alguma forma Rui Barbosa deixava também transparecer sua voz em meio ao texto de Janus.

Direitos das Mulheres e injustiça dos Homens, traduzido livremente do francês por Nísia Floresta Brasileira Augusta ${ }^{4}$, é a versão brasileira de $A$ vindication of rigths of Woman, de Mary Wollstonecraft. Segundo Constância Lima Duarte (1989, p. 107-108):

$\mathrm{Na}$ verdade - e quem conhece o original já percebeu - Nísia não realiza propriamente uma tradução do texto da feminista. Ela realiza, sim, um outro texto, o seu texto sobre o direitos das mulheres. Mary Wollstonecraft lhe dá a motivação ao colocar em letra impressa questões pertinentes à mulher inglesa, voltadas naturalmente para o público de seu país. Nísia como que realiza uma "antropofagia libertária". E poderíamos ainda acrescentar: não como opção, mas até como fatalidade histórica. Na deglutição geral das ideias estrangeiras, era praxe promover-se uma acomodação de tais idéias ao cenário nacional. É o que ela faz. Assimila as concepções de Mary Wollstonecraft e devolve um outro produto, pessoal, em que cada palavra vivida, em que os conceitos surgem das páginas como algo visceral, extraído da própria experiência e mediatizados pelo intelecto.

De fato, por muito tempo se acreditou que o texto de Mary Wollstonecraft havia sido traduzido por Nísia, mas, na verdade, o que a feminista brasileira traduziu foi o

\footnotetext{
${ }^{4}$ Ao lado de Nísia Floresta (que além de tradutora, também foi jornalista, escritora e autotradutora), registram-se mais de 20 tradutoras do século XIX, lista que pode ser consultada no livro Mulheres de Ontem? Rio de Janeiro- século XIX, de Maria Thereza Caiuby Crescenti Bernardes (São Paulo, T. A. Queiroz, 1988).
} 
texto de alguém com o pseudônimo "Sophia, a Person Quality” intitulado Woman not Inferior to Man (1739) que é plagiado em grande parte do texto de Poulain de La Barre, a saber De l'Égalité des Deux Sexes (1673), sem citá-lo em momento algum (PallaresBurke, 1996). Por isso, em conformidade com Constância Lima Duarte, podemos dizer que realmente era outro texto e, mais, o fato desse texto ter sido publicado no Brasil com o nome da feminista inglesa se justifica porque Nísia Floresta precisava de um respaldo para ser identificada não como autora, mas como mediadora de ideias progressistas europeias, além de ter sido uma homenagem prestada por ela mesma como uma grande admiradora brasileira de Mary Wollstonecraft (Pallares-Burke, 1996). Entretanto, pode-se constatar que tal tradução ecoou como um dos primeiros manifestos do feminismo brasileiro, sendo mencionada indiretamente nos trabalhos da romancista gaúcha Ana Eurídice Eufrosina de Barandas (1806 - ?) e até mesmo no romance $A$ moreninha (1844) de Joaquim Manuel de Macedo (Duarte, 1989).

Outro tradutor que chamou atenção nesta época, não somente pelo fato de ter sido um negro escolarizado, mas por ser filósofo, poeta, crítico, jurista e fundador da Escola do Recife, foi Tobias Barreto (1838-1889). Avesso às ideias dominantes do período e proeminentes quase que na totalidade da França, torna-se o precursor do germanismo no Brasil. Sabendo a língua alemã, foi o pioneiro no estudo e na difusão de obras e ideias filosóficas alemãs em solo nacional. Verteu para o alemão um folheto intitulado Brasilien wie es ist (O Brasil como ele é) a fim de divulgar a cultura brasileira no Alemanha no século XIX. Traduziu filósofos como Ludwig Büchner, Jacob Moleschott e Ernest Haeckel e escritores como Ernst Hoffmann. Além dessas traduções, Barreto também editou o periódico Deutscher Kämpfer (O lutador alemão), entre tantas outras obras sobre filosofia alemã, como, por exemplo, Estudos Alemães em 1879. Foi um grande agente de tradução (Duval, 2013) porque utilizou o viés da tradução para influenciar uma cultura-alvo, no caso, a brasileira, promovendo assim seus interesses literários, políticos e pessoais. Somado a isso, vale lembrar que Tobias Barreto abre um novo paradigma do ato tradutório no Brasil: enquanto a quase totalidade das traduções do século XIX eram feitas a partir de uma tradução-piloto francesa, ele será um dos poucos tradutores desta época que traduzirá diretamente da língua fonte.

Aludindo ainda à questão da tradução e difusão de ideias subversivas que ocasionaram mudanças de paradigmas, cabe mencionar que o século XIX brasileiro teve uma enorme profusão de jornais e revistas com os mais diferentes propósitos, especialmente na sua primeira metade. À medida que a censura ainda não se instaurava 
definitivamente, muitos jornais e revistas feitos no Brasil dependiam uns dos outros uma mesma notícia era publicada, por vezes, em diferentes jornais e revistas do país e também de notícias estrangeiras que eram por sua vez traduzidas em vernáculo ou difundidas na língua dos eruditos, ou seja, a língua francesa. Porém, era comum, notadamente para os jornais/revistas de cunho moralista ou de ideias progressistas, a apropriação de matérias jornalísticas traduzidas à moda brasileira — isto é, adaptadas ao solo nacional — sem a citação da fonte. Muitas vezes, quando o artigo era de uma pessoa renomada no exterior, mencionava-se sua autoria, do contrário, o registro de tal autor era sem importância porque corria à época que o primordial era a difusão das ideias.

A revista $O$ progresso (Social, Literária e Científica) que circula no Brasil entre os anos de 1846 e 1848, fundada por Antônio Pedro de Figueiredo, trazia muitas traduções, como os temas da Lei Agrária, O comunismo na Alemanha, O Socialismo na Suíça, Doutrina de Saint-Simon, dentre outras. Algumas com a autoria, outras não. Mas todas sem o nome do tradutor, com indícios de que seja o próprio editor e fundador da revista, já que era reconhecido pelas suas traduções História da Filosofia, de Victor Cousin, Da Soberania do Povo e dos Princípios do Governo Republicano Moderno, de Ortolan, e As setes cordas da Lira, de George Sand. Esse periódico, segundo o próprio Antônio Pedro de Figueiredo, ao mesmo tempo que servia de

asilo ao livre pensamento, às considerações serenas da filosofia e da ciência', alerta para a tendência à época de 'copiar servilmente a Europa', propondo então o caminho da "aplicação ao nosso país dos dados das ciências sociais", buscando "os germes de um futuro generoso". (Gonçalves, 2004, p. 5)

Esse periódico tornou-se um dos principais difusores do fourierismo no Brasil, ou seja, do pensamento de Charles Fourier (1772-1837) no que concerne ao socialismo crítico-utópico baseado, dentre outras noções, na crítica ao capitalismo, à civilização urbana, à industrialização, ao matrimônio, à monogamia.

Já O Carapuceiro (1832-1847), importante jornal de Pernambuco durante o período regencial (1831-1840), escrito por Miguel do Sacramento Lopes Gama padre, educador, político e jornalista —, foi um dos periódicos de maior sucesso no século XIX por retratar a contemporaneidade da sociedade recifense. O periódico tratava de uma gama muito ampla de assuntos: dos modismos estrangeiros às revoltas do período, de bons costumes à política exercida à época, de brancos a negros. Tirando as traduções em que a autoria era mencionada, pensava-se que todos os artigos eram da 
lavra de Lopes Gama; os ditos de temas mais importantes (como a venda de escravos, as revoltas republicanas, o comportamento irreligioso, etc.) eram mesmo de sua autoria; todavia, assuntos menos relevantes, mas que ao mesmo tempo deviam constar no jornal - como, por exemplo, o comportamento feminino da época - eram plágios de artigos ingleses adaptados para as mulheres brasileiras.

Segundo Maria Lúcia Garcia Pallares-Burke (1996, p.143), “os artigos sobre mulheres em $O$ Carapuceiro, foram, em parte, extraídos de um texto não apenas estrangeiro, mas publicado mais de cento e vinte anos antes". Ou seja, esses artigos a que se refere a pesquisadora foram originalmente publicados no periódico inglês The Spectator (1711-1712, 1714) e de alguma forma retrabalhados para que o artigo em português tivesse "uma cara brasileira". Toda a retórica desses textos era a mesma do texto em inglês, assim como seus temas. Entretanto, os acréscimos assim como as omissões traziam "infidelidades criativas" — para usar as palavras de Pallares-Burke — revelando uma leitura enriquecedora e inovadora do texto, bem como transformações sofridas na passagem de uma língua à outra quase como na prática das Belles infidèles na França. Se, por um lado, tal fato revela que a mentalidade da mulher brasileira à época era igual à mentalidade da mulher inglesa do século XVIII, no que tange à tradução, esse ato de Lopes Gama enfatiza ainda mais que nesse período a apropriação de ideias (subversivas ou não) por intermédio da tradução e a invisibilidade da autoria (seja do tradutor como do escritor não-célebre do texto fonte) eram práticas recorrentes.

\section{Tradução de textos religiosos}

No campo da religião, a tradução, tanto no que tange aos tradutores de textos religiosos — ou seja, ao processo — quanto na divulgação, distribuição e acesso de tais textos - a saber, o produto em si —, foi uma importante ferramenta de doutrinação (especialmente no caso do Espiritismo) e de expansão de ensinamentos até então transmitidos apenas oralmente (o caso do Cristianismo) no período anterior ao século XIX no Brasil. Além disso, a tradução de tais textos ocasionou uma série de malentendidos e discussões.

A Bíblia em língua portuguesa, até então livro proibido no Brasil oitocentista (Hallewell, 2005), começa a ser oficialmente permitida em 1842 com a versão ${ }^{5}$ do padre

\footnotetext{
${ }^{5}$ Esta versão se prolonga por 18 anos, iniciando em 1778 e finalizando em 1821. Entre 1778 e 1781 traduz-se o Novo Testamento. De 1782 a 1790, o Antigo Testamento. Em 1819, publica-se uma versão reduzida e padrão e, em 1821, uma versão de volume único.
} 
português Antônio Pereira de Figueiredo que não incluía os livros apócrifos. Tal tradução, distribuída com maior vigor pelos protestantes ou por missionários estrangeiros não-católicos no Brasil, foi considerada como "bíblia falsificada" (Bueno \& Ermakoff, 2005). Sofreu duras críticas, desde artigos condenando o tal livro por apresentar uma bíblia truncada e manipulada até mesmo queima pública de bíblias (Costa, 2009). De fato, a primeira tradução da Bíblia, ainda parcial porque era somente da Vulgata (Novo Testamento), foi feita em 1847 pelo bispo do Maranhão D. Fr. Joaquim de Nossa Senhora da Nazaré; a primeira tradução publicada no Brasil em 1879 foi realizada diretamente do grego por José Manoel Garcia, Modesto Perestrello Barros Carvalhosa e Alexandre Latimer Blackford. Entretanto, a publicação e tradução da Bíblia completa no Brasil só ocorreu em 1898. Era a edição revista e corrigida da primeira tradução de que se tem conhecimento da Bíblia em língua portuguesa, a versão de João Ferreira de Almeida de 1748 (Carrez, 1995, p. 21).

Também outros livros de cunho cristão foram traduzidos no Brasil nesse período, como o Catecismo bíblico, do bispo McTyeire, e a Disciplina metodista, ambos em 1877 e, em 1878, Compêndio de oração, traduzidos por Alexandre Latimer Blackford. Contudo, um fato que chama bastante a atenção nesse período foi a crescente difusão de obras literárias traduzidas de cunho religioso, mais particularmente protestante, que circulavam à época. Segundo Karla Janaína Costa Cruz (2014), as narrativas ficcionais de discurso protestante eram primeiramente publicadas em jornais laicos e logo em seguida, após seu sucesso como folhetim, vendidas como livros. Exemplo disso é a tradução empreendida pelo missionário escocês Robert Reid Kalley do livro O Peregrino, de John Bunyan (clássico da literatura religiosa inglesa escrito no século XVIII), que teve sua circulação inicialmente em folhetins do Jornal Correio Mercantil ao longo do ano de 1856 visando a difusão da propaganda evangélica e a instrução doutrinária por meio da leitura. Vale mencionar que no Oitocentos houve uma grande profusão de jornais protestantes que traziam, dentre suas diversas rubricas, traduções de artigos, citações de pessoas importantes, orações, estudos bíblicos, tratados teológicos, além das prosas ficcionais didatizantes.

O Espiritismo talvez tenha a sido a religião que ganhou mais adeptos no século XIX por intermédio de traduções. Joaquim Carlos Travassos (1839-1915), médico e político, sabendo francês e adepto fervoroso do Espiritismo, traduz a partir de 1875, ora sob pseudônimo de Fortúnio, ora sem, as quatro principais obras do kardecismo: $O$ Livro dos Espíritos, O Livro dos Médiuns, O Céu e o Inferno e $O$ Evangelho segundo o 
Espiritismo. Incentivado e iniciado por Travassos nesta doutrina, Adolfo Bezerra de Menezes Cavalcanti também traduz em língua portuguesa as Obras Póstumas de Allan Kardec em 1892. Todas essas versões da doutrina espírita nortearam o grande crescimento de seus seguidores, assim como a fundação de federações, sociedades e comunidades espíritas em todo o Brasil. E assim como os cristãos protestantes, os espíritas da época também se utilizavam do jornal para publicar artigos sobre o Espiritismo ou partes de livros de Allan Kardec ainda não publicados no Brasil. Dentre esses periódicos, podemos destacar o Echo d'Além túmulo (1869-1871) publicado na Bahia bimestralmente e que apresentava inúmeras traduções de textos de Allan Kardec ou artigos sobre o espiritismo publicados em periódicos europeus, sobretudo franceses — o texto "O que ensina o espiritismo?", por exemplo, é uma versão da Revue Spirite de 1869 (Jesus, 2012).

Cabe ressaltar ainda que na Bahia do século XIX, local de onde se difundia com maior força o Espiritismo, existia uma grande concentração de negros africanos oriundos do tráfico de escravos. Dentre tais negros, com diferentes religiões e níveis de letramento, havia a manutenção de uma das grandes religiões da África: o Islamismo. Após libertos, pela lei da abolição da escravatura no Brasil, muitos eram os negros que gostariam de ter acesso às leis sagradas do Alcorão e, segundo a pesquisadora Priscilla Leal Mello (2009), há indícios de que a esta época excertos do Alcorão, pequenos textos e orações referentes ao culto mulçumano, tenham recebido traduções e versões.

\section{Tradução literária}

Com a importação de correntes literárias e de novos elementos estéticos e discursivos, a tradução não apenas propiciou a consolidação da literatura no Brasil do século XIX, como também a popularização da imprensa nacional, com a publicação de folhetins e romances traduzidos, destinados a fortalecer o mercado editorial e a fidelizar o público leitor. O romance-folhetim traduzido, além de assegurar o início do mercado editorial brasileiro, foi o grande responsável por lançar modismos europeus no Brasil, principalmente entre as mulheres da burguesia que consumiam tal literatura (Meyer, 1996). Muitos dos romances-folhetins eram traduzidos e logo depois lançados em livro, o que impulsionou o hábito de adquirir livros e também de comercializá-los. No caso do romance $O$ homem que ri, de Victor Hugo, por exemplo, sua publicação em folhetim no Brasil precedeu, segundo o Diário do Rio de Janeiro de 23/05/1869, a publicação do 
romance na França. Posteriormente, o romance foi publicado no Brasil em formato de livro (Reis, 2012).

Outro domínio do campo literário que recebeu forte influência estrangeira no oitocentismo brasileiro foi o teatro. Podemos constatar isso em uma das críticas de Machado de Assis, que afirmava que desse tipo de tradução nascia "uma entidade: o tradutor dramático, espécie de criado de servir que passa, de uma sala a outra, os pratos de uma cozinha estranha" (Assis, 1938).

À época, muitas foram as óperas, vaudevilles e tragédias adaptadas ou traduzidas do francês, italiano, espanhol e alemão para o público brasileiro, o que levou à abertura do Conservatório Dramático Brasileiro (1843-1871), que passou a determinar os padrões linguísticos do nosso teatro e sofreu muitas críticas como esta, de Machado de Assis (1938):

\begin{abstract}
Não podia o Conservatório tomar um encargo no sentido de fazer desenvolver o elemento dramático na literatura? As vantagens são evidentes - além de emancipar o teatro, não expunha as platéias aos barbarismos das traduções de fancaria que compõem uma larga parte dos nossos repertórios.
\end{abstract}

Consequentemente, críticas como esta entrelaçadas à prática da tradução de peças teatrais impulsionaram de forma decisiva a criação de textos dramáticos nacionais. Podemos evidenciar ainda neste âmbito a Livraria Tavares Cardoso \& Irmão que, em meados do século XIX, em Belém do Pará, foi também a responsável pela publicação e divulgação de várias traduções de peças e adaptações de romances para o teatro, feitas por Augusto Garraio (Garcia, 2012).

A influência de escritores como Victor Hugo, lido no original ou por meio de tradução, inspirou muitos escritores brasileiros como Machado de Assis, Aluízio Azevedo, Castro Alves e Olavo Bilac (Ferreira, 2004). Podemos citar aqui, a título de ilustração, a obra Hugonianas, antologia de poesia traduzida, organizada por Mucio Teixeira e que homenageia Victor Hugo no ano de sua morte (1885). Entre os tradutores desta obra, sobressaem os nomes de Castro Alves, Gonçalves Dias, Casimiro de Abreu, Vicente de Carvalho, Artur Azevedo, Raimundo Correia e o próprio Mucio Teixeira. Diante disso, percebemos que muitos foram os escritores e os intelectuais tradutores no século XIX, mas poucos deles são ainda lembrados por sua contribuição nessa área.

José Feliciano de Castilho, irmão de Antônio Feliciano de Castilho, um dos defensores do ultrarromantismo português, é um exemplo de tradutor intelectual desse período. Castilho José, como também era chamado, foi um dos principais tradutores de 
latim no Brasil Império, viveu no Rio de Janeiro entre 1847 e 1879, e era editor, redator, filólogo e latinista. Suas principais traduções são as obras Fasália, de Lucano, e Amores e Arte de Amar, de Ovídio. Ele tem sua importância garantida no Império Brasileiro por suas traduções serem notoriamente reconhecidas e mesmo criticadas por Machado de Assis e pelo Imperador Dom Pedro II $^{6}$. Além das traduções de Castilho José constarem na Biblioteca de Dom Pedro II, José Feliciano de Castilho era convidado para lê-las em saraus diante do imperador, o que constata a circulação/divulgação do legado grecoromano e a sedimentação de tendências literárias clássicas no Segundo Império brasileiro (Vieira, 2010).

Salientamos ainda que, no campo literário, obras importantes sobre a História da Literatura no Brasil foram publicadas no exterior: Geschichte der Portugiesischen Poesie und Beredsamkeit (1804), de Friedrich Bouterwek, De la littérature du Midi de l'Europe (1819), de Simonde de Sismondi, Résumé de l'histoire littéraire du Portugal (1825), de Ferdinand Denis e Le Brésil Littéraire (1863), de Ferdinand Wolf (Romero, 1960). Todas elas só iriam ser traduzidas a partir do século seguinte (Zilberman, 2013), sendo a obra em alemão nunca traduzida e pouco mencionada até os dias de hoje. Ora, tal dado da não-tradução de obras tão importantes para os Estudos Literários no Brasil nos direciona a duas conclusões: primeiro, de que nesse período a língua francesa era tão difundida que a elite e os grandes intelectuais, inclusive os que se dedicavam aos estudos da literatura nacional, sabiam ler e escrever nessa língua estrangeira e daí a nãonecessidade de traduzir; segundo, o conhecimento difundido em francês era direcionado a um grupo seleto, sendo a tradução ou a necessidade de traduzir um movimento/produto de massa com um objetivo comercial da literatura no século XIX.

Fora do horizonte da literatura canônica à moda dos críticos literários deste período, em conjunto com o poder de consumo popular e a prosperidade do mercado livreiro, nasce ainda no Oitocentos dois tipos de Literatura que originalmente são procedentes do ato tradutório: a literatura infantil e a literatura pornográfica.

Em 1894, o editor e livreiro Pedro da Silva Quaresma, no Rio de Janeiro, querendo alcançar todos os públicos, lança a chamada Biblioteca Infantil que, inicialmente, "reuniu contos populares traduzidos de vários países, sobre os mais diversos assuntos [..], além de fábulas, poesias para serem declamadas nos serões

\footnotetext{
${ }^{6}$ Dom Pedro II, além de crítico de tradução, também foi tradutor. Traduzindo desde textos religiosos (o livro de Neemias do Antigo Testamento, por exemplo) a obras literárias (Mil e uma noites, dentre tantas outras). Mais informações sobre o assunto em Dom Pedro II: Um tradutor imperial (Soares, N.; Souza, R.; Romanelli, S. (orgs.). Florianópolis, Tubarão, 2013.)
} 
familiares, peças fáceis de serem decoradas e encenadas por meninos e meninas, cantigas de berço, jogos e divertimentos para todas as idades" (El Far, 2004, p. 94). Mas não somente no Rio de Janeiro poderiam ser encontradas traduções de literatura infantil: em outros lugares do Brasil eram também populares As aventuras pasmosas do Barão de Munkausen (181?); O Último dos Moicanos (1838), de Fenimore Cooper, em tradução de Caetano de Lopes Moura; Aventuras do Barão de Münchhausen (1848); obras de Júlio Verne traduzidas por Jovina Cardoso; obras de Alexandre Dumas traduzidas por Ciro Cardoso; O canário (1856), A cestinha de flores (1858) e Os ovos de Páscoa (1860), de Cônego (Christoph) von Schmid; e Joãozinho (1858), de Charles Jeannel, traduzido por Antônio Rêgo. Esses livros tornaram-se muito populares, assim como as versões brasileiras de narrativas de Charles Perrault, dos Irmãos Grimm e de Andersen que muitas vezes eram traduzidas, primeiramente, em Portugal e aqui comercializadas.

Por sua vez, a literatura pornográfica também alcançou seu auge por ser de fácil leitura e causar sensações no leitor, especialmente, entre os homens (El Far, 2004). A estética literária do naturalismo, assim como as ideias anticlericais, foram um grande incentivo para a circulação, feitura e consumo de tais traduções no Brasil. Livros como Miss Fanny (Fanny Hill ${ }^{7}$ - 1748), de John Cleland; Teresa filósofa ${ }^{8}$ (Thérèse Philosophe - 1748), atribuído a Jean-Baptiste de Boyer, Marquês d'Argens; Memórias de frei Saturnino ${ }^{9}$ (Histoire de don Bougre, Portier des Chartreux - 1715), de Gervaise de

\footnotetext{
${ }^{7}$ A obra é considerada o primeiro romance erótico inglês e tornou-se sinônimo de batalha contra a censura por ser um dos livros mais censurados da história. O enredo relata a história de Fanny que, abandonada à sorte devido à morte de seus pais aos 15 anos, vai tentar a vida em Londres e acaba sendo criada por uma cafetina que queria leiloar sua virgindade. Fanny se apaixona por Charles e perde sua virgindade contrariando o desejo da cafetina. Porém, Fanny é separada de Charles e expulsa do prostibulo. Logo, ela se torna uma verdadeira prostituta e vivencia várias situações de prostituição, passando pela miséria, libertinagem, orgias, luxúrias, homossexualismo e doenças venéreas. Com um dos seus últimos clientes se casa e herda sua fortuna. Rica, procura Charles e se casa com ele.

${ }^{8} \mathrm{O}$ texto faz parte de uma vasta onda de ficção erótica impressa e reimpressa na derrocada do Antigo Regime francês que desafiou os preceitos religiosos e morais, misturando sexo e filosofia, cópula e metafísica, libertinagem e livre pensamento. A trama da narrativa se passa em torno da personagem principal, Teresa, que primeiro, descobre o sexo observando as seduções praticadas pelo padre Dirrag com uma de suas devotas, mademoiselle Eradice. Depois, entra em contato com o pensamento filosófico em conversas com a sra. $\mathrm{C}$ e o abade $\mathrm{T}$. E conhece a existência das perversões amorosas acompanhando a prostituta aposentada Bois-Laurier para, enfim, se tornar a amante de um conde.

${ }^{9} \mathrm{O}$ livro descreve as aventuras rocambolescas, libertinas e licenciosas de um monge. O romance é contado a partir da primeira pessoa na visão da história de vida do monge B. (a sigla significa Bougre, uma expressão vulgar francesa para pederasta), cujo nome secular é Saturnino. Saturnino tem sua primeira relação sexual com sua irmã e sua mãe Suzana. Mais tarde, ele saberá que na verdade não existe nenhuma relação de sangue. Vai experimentar todas as variedades de desinibição sexual no curso de muitas cenas de humor até que, finalmente, contrai sífilis ao deitar com sua irmã doente em um bordel. Ela morre no dia seguinte e ele, doente, é à força castrado, a fim de salvar a sua vida. No final Saturnino é recebido em um mosteiro, onde, liberto de todas as paixões, pode esperar pela morte.
} 
Latouche, dentre os célebres Dama das Camélias (1856), de Alexandre Dumas Filho, Nana (1880), de Emilie Zola, Madame Bovary (1856), de Gustave Flaubert e La religieuse (1796), de Denis Diderot (todos considerados pornográficos ou imorais, ora com cenas mais quentes, ora com cenas brandas de sexo explícito), faziam muito sucesso e eram vendidos a um preço pequeno para que todos tivessem acesso a essa leitura. Tais traduções incentivaram escritores brasileiros à feitura de obras do mesmo gênero. Ademais os aspirantes a escritores, muitas vezes passavam primeiramente pelo estágio de tradutor para assim começar sua carreira literária (Esteves, 2003).

Em ambos os gêneros populares de literatura (a infantil e a pornográfica), o formato também contribuía para a venda. Aliás, também se traduzia tais gêneros em periódicos (revistas, jornais, folhetos) para depois os comercializarem como livro. Esses dois tipos de literatura recebiam igualmente também outro tipo de tradução: a tradução intersemiótica. Tais livros, jornais, folhetos e revistas tanto de literatura infantil como de literatura pornográfica eram vendidos, em sua maioria, com inúmeras ilustrações, gravuras, desenhos e fotos que serviam ora para reforçar momentos da trama, ora para facilitar a leitura. Este período será marcado fortemente por esse entrelaçamento de imagem e texto, quer sendo a tradução um do outro, quer sendo um discurso complementar de acompanhamento, na maioria das vezes, da tradução escrita e, sobretudo, a literária.

\section{Tradução, Língua Nacional e discurso do tradutor e sobre a tradução}

A tradução no Oitocentos possibilitou ainda a ampliação do léxico, com a domesticação de palavras e expressões estrangeiras - como os vocábulos abajur, marrom, balé, carmim, bufê, bibelô, chofer, garagem e muitos outros oriundos da língua francesa —, a criação de neologismos e a consolidação de uma escrita literária em português do Brasil, conforme Edith Pimentel Pinto (1978, p. LVII): "Cronologicamente, observa-se a lenta formulação do pensamento crítico a respeito da língua que não começa a emergir senão nos meados do século XIX”. E um dos mais importantes defensores de uma autonomia da língua literária brasileira, José de Alencar, assim se manifestava: "Em Portugal o estrangeiro perdido no meio de uma população condensada pouca influência exerce sobre os costumes do Povo: no Brasil, ao contrário, o estrangeiro é um veículo de novas ideias e um elemento da civilização nacional" (apud Pinto, 1978, p. 76). Esse pensamento será reformulado mais adiante por Coelho 
Neto, ao dizer: "As línguas evoluem e eu admito, como necessidade de representação de ideias, o estrangeirismo" (ibid., p. 399).

O discurso linguístico a respeito da língua nacional é repleto de comparações entre o português de Portugal e o português do Brasil no século XIX. Não é de se admirar que a tradução seja uma dessas metodologias de afirmação da língua nacional conforme atestamos no texto de José Bonifácio intitulado "Advertência" (à tradução de Ode Primeira das Olímpicas de Píndaro) em que o autor tenta diferenciar as duas línguas por intermédio da tradução de um texto latino. A obra O português do Brasil: textos críticos e teóricos organizada por Edith Pinto (1978) traz inúmeros textos de autores oitocentistas que utilizam a metodologia do texto traduzido a fim de justificar, explicar ou mesmo criar determinado vocábulo ou expressão no idioma brasileiro.

Além dos textos a respeito da língua, é possível identificar textos que trazem o assunto da tradução e dos tradutores nos folhetins publicados no século XIX. Várias são as publicidades a respeito das traduções, ora com críticas, ora com louvor. Também é comum encontrar os mais diversos elogios aos tradutores de obras literárias, técnicocientíficas, ou mesmo de artigos de jornal. O fato é que o discurso do tradutor e sobre a tradução fazia parte direta ou indiretamente da argumentação dos homens de letras desse período. Somados a isso, gêneros textuais diretamente ligados à tradução nunca foram tão usuais como nessa época. Notas de rodapé, introduções, prefácios e até mesmo posfácios começaram a proliferar com muita intensidade, mesmo não revelando, majoritariamente, o nome e a identidade do tradutor. Por vezes, tais gêneros textuais vinham carregados dos discursos do próprio tradutor com desculpas por palavras intraduzíveis ou buracos de tradução, comentários sobre tal trecho/texto traduzido, explicações para um novo vocábulo até então não existente em português, mas oriundo do ato tradutório - Machado de Assis, assim como tantos outros, é exemplo disso.

\section{À guisa de conclusão}

É fato que, para formarmos uma História da Tradução, é necessário que pesquisadores deste domínio adentrem os mais variados estudos historiográficos, visto que a história a ser construída e delineada é multidisciplinar e encontra-se dispersa como um quebra-cabeça a ser montado. Há ainda um longo caminho a ser traçado a fim de mostrarmos os homens, as mulheres, as obras, os mecanismos, as ideologias e as esferas da tradução para uma escrita testemunhal, consistente e crítica da historiografia da tradução e, consequentemente, sólida contribuição ao Estudos de Tradução no Brasil. 
Faz-se necessário resgatar o passado para entendermos um pouco de nossa herança tradutória, e indubitavelmente o século XIX é o momento de maior mudança de paradigmas, bem como de bens deixados a serem estudados no presente, quando comparado aos séculos anteriores.

Em suma, no século XIX o conhecimento vinha da Europa e era introduzido no Brasil graças à tradução. Foi por meio da tradução que a sociedade teve acesso a conhecimentos científicos, filosóficos, artísticos e até mesmo libertinos que influíram diretamente na vida cultural e social do país. Ressalto ainda as palavras de Wyler (1999, p. 99) que diz que

Nas ex-colônias europeias - o caso do Brasil - ao invés deste intercâmbio lento, variado e multidirecional [da tradução na Europa], o que ocorreu foi um transplante cultural intenso e unívoco. A tradução, ao invés de fertilizar culturas nacionais, contribuiu de forma decisiva para construir culturas hegemônicas de substituição.

O Brasil é um dos casos de consolidação de cultura hegemônica através da tradução, o que tentamos demonstrar, em parte, durante toda esta exposição de fatos do século XIX no presente trabalho. E nossa breve exposição sobre a força e o importante papel da tradução no século XIX nos permite considerar que sua atuação é pouco ressaltada pelos estudos de História e pela historiografia da literatura brasileira. Tal "esquecimento" torna tanto a tradução como seu agente-produtor (o tradutor) categorias marginalizadas em suas relações com outras áreas do conhecimento, assim como enfraquece sua contribuição para a própria história de nossa sociedade, além de mostrar um estigma ainda contemporâneo: a invisibilidade do tradutor, a invisibilidade da tradução.

No Brasil, ainda são poucos os estudos sobre o oitocentismo que revelam a importância da tradução e do tradutor como agentes de globalização cultural e intelectual; que mostram o papel da tradução em momentos históricos brasileiros; que revelam a compreensão de elementos formadores da cultura - literatura, imprensa, língua nacional, dentre outros - graças ao ato tradutório; e que explicam o processo de apagamentos de fronteiras nacionais na globalização do espaço sociocultural e literário por meio da tradução no século XIX. 


\section{Referências}

ASSIS, Machado. Idéias sobre o Teatro. 1838. Disponível em: $<$ http://machado.mec.gov.br/images/stories/html/critica/mact02.htm $>$. Acesso em 15 set. 2012.

BAKHTIN, Mikhail; VOLOSHINOV, V. Marxismo e filosofia da linguagem. Tradução de Michel e Yara Vieira. 6a . ed. São Paulo: Hucitec, 1992.

BARBOSA, Rui. Prefácio. In: JANUS. O papa e o concílio. Tradução e introdução de Rui Barbosa. Rio de Janeiro: Brown \& Evaristo editores, 1877. Disponível em: <http://www2.senado.leg.br/bdsf/item/id/222262>. Acesso em 20 fev. 2015.

BONIFÁCIO, José. Advertência (à tradução de Ode Primeira das Olímpicas de Píndaro). In: PINTO, Edith P. O português do Brasil: textos críticos e teóricos. I 1820/1920 - fontes para a teoria e a história. Rio de Janeiro, LTC; São Paulo, Edusp, 1978.

BUENO, Alexei; ERMAKOFF, George (Orgs). Duelos no serpentário: uma antologia polêmica intelectual no Brasil - 1850-1950. Rio de Janeiro: G. Ermakoff, 2005.

CANO, Jefferson; TOLEDO, Edilene. Imigrantes no Brasil do século XIX. São Paulo: Atual, 2003.

CARREZ, Maurice. A bíblia. Tradução de Marcos Bagno. São Paulo: Loyola, 1995.

CASTELlANOS. Samuel L. V. O livro escolar no Maranhão Império: produção, circulação e prescrições. 2012. 456 pág. Tese (Doutorado em Educação). Programa de Pós-Graduação em Educação Escolar, Universidade Estadual Paulista Júlio de Mesquista Filho-UNESP, 2012.

COSTA, Hermisten M. P. O Protestantismo e a Palavra Impressa: Final. Ciências da religião (Mackenzie. Online), v. 07, 2009. Disponível em: $<$ http://editorarevistas.mackenzie.br/index.php/cr/article/download/1182/>. Acesso em 23 fev. 2015.

CRUZ, Karla J. C. Cultura Impressa e Prática leitora Protestante no Oitocentos. 2014. 263 pág. Tese (Doutorado em Linguística). Programa de Pós-Graduação em Linguística, Universidade Federal da Paraíba - UFP, 2014.

DUARTE, Constância L. Posfácio: Nos primórdios do feminismo brasileiro. In: AUGUSTA, Nísia F. B. Direitos das Mulheres e Justiça dos Homens. Introdução e notas de Constância Lima Duarte. São Paulo: Cortez, 1989. 
DUVAL, Roch. Tobias Barreto e o papel determinante dos impressos na mudança do paradigma tradutológico no final do século XIX. Quebec: mimeo, 2013.

EL FAR, Alessandra. Páginas de sensação: literatura popular e pornográfica no Rio de Janeiro (1870-1924). São Paulo: Companhia das Letras, 2004.

ESTEVES, Lenita M. R. A tradução do romance-folhetim no século XIX brasileiro. In: Trabalhos em Linguística Aplicada, v. 42, 2003. Disponível em: < http://revistas.iel.unicamp.br/index.php/tla/article/view/2255/1784>. Acesso em 02 mar. 2015.

FÉDER, João. Pagando uma dívida: Rui Barbosa. Disponível em : $<$ http://www.joaofeder.jor.br/index.php?pag=noticia\&idnoticia=495\&idmenu=56\& conjunto $=\&$ idusuario $=\&$ noticias $=\&$ idloja $=>$. Acesso em 15 set. 2012.

FERREIRA, Eliana F. Cunha. Para traduzir o século XIX - Machado de Assis. São Paulo: Annablume, 2004.

FREITAS, Renata R. “O que liam esses homens?”: Divulgação de livros nos jornais O Paiz e Gazeta de Notícias (1880-1890). Disponível em: $<\mathrm{ttp}: / /$ www.espea.iel.unicamp.br/textos/IDtextos66pt.doc >. Acesso em 15 set. 2012.

GARCIA, Izenete Nobre. A circulação transatlântica de obras literárias entre Belém e Lisboa: o caso da livraria e editora de Tavares Cardoso \& Irmão. Disponível em: <http://www.espea.iel.unicamp.br/textos/IDtextos55pt.pdf>. Acesso em 14 set. 2012.

GONÇALVES, Adelaide. “As comunidades Utópicas e os primórdios do socialismo no Brasil”. E-topia: Revista Electrónica de Estudos sobre a Utopia, n. 2, 2004. Disponível em: 〈http://ler.letras.up.pt/uploads/ficheiros/artigo10561.pdf> . Acesso em 22 fev. 2015.

HALLEWELL, Laurence. O livro no Brasil. $2^{\mathrm{a}}$ ed. revista e ampliada. Tradução de Maria da Penha Villalobos, Lólio Lorenço de Oliveira e Geraldo Gerson de Souza. São Paulo: EDUSP, 2005.

JESUS, Leonardo F. Écho D’além Túmulo: Imprensa e Difusão do Espiritismo no Brasil (1869-1870). In: Anais da ABHR (Associação Brasileira de História das Religiões) - Religião, carisma e poder: As formas da vida religiosa no Brasil. São Luís, UFMA, 2012. Disponível em: $<$ http://www.abhr.org.br/plura/ojs/index.php/anais/article/view/605>. Acesso em 25 fev. 2015. 
MELLO, Priscilla L. Leitura, encantamento e rebelião: o Islã negro no Brasil no século XIX. 2009. 298 pág. Tese (Doutorado em História). Programa de PósGraduação em História, Universidade Federal Fluminense - UFF, 2009.

MEYER, Marlyse. Folhetim: uma história. São Paulo: Companhia das Letras, 1996.

OLIVEIRA, José C. A cultura científica e a Gazeta do Rio de Janeiro (1808-1821). Revista da SBHC, n. 17, 1997. Disponível em: <http://www.mast.br/arquivossbhc/146.pdf.>. Acesso em 20 fev. 2015.

PAES, José Paulo. Tradução a ponte necessária. São Paulo: Ática, 1990.

PALLARES-BURKE, Maria L. G. Nísia Floresta: O Carapuceiro e outros ensaios de tradução cultural. São Paulo: HUCITEC, 1996.

PALMA, Patrícia F. M. J.. Mercado do livro brasileiro em Portugal (1850-1914). Disponível em: <http://www.espea.iel.unicamp.br/textos/IDtextos75pt.pdf>. Acesso em 14 set. 2012.

PINTO, Edith P. O português do Brasil: textos críticos e teóricos. I - 1820/1920 fontes para a teoria e a história. Rio de Janeiro, LTC; São Paulo, Edusp, 1978.

REIS, Dennys S. O romance hugoano L'homme que rit: estudo crítico, tradução e retradução para o português do Brasil. Arena Romanistica - Translation, v. 10, p. 298-312, 2012.

ROMERO, Silvio. História da Literatura Brasileira. Vol. 1. Rio de Janeiro: José Olympio, 1960.

VEIGA, Cláudio. Um brasileiro soldado de napoleão. São Paulo: Ática, 1979.

VIEIRA, Brunno V. G. Um tradutor de latim sob D. Pedro II: perspectivas para a história da tradução da literatura greco-romana em português. Revista Letras. Curitiba, n. 80, p. 71-87, jan./abr. 2010. Disponível em: $<$ http://ojs.c3sl.ufpr.br/ojs/index.php/letras/article/view/17072/14760>. Acesso em 8 de junho 2015.

WYLER, Lia. Línguas, poetas e bacharéis - uma crônica da tradução no Brasil. Rio de Janeiro: Rocco, 2003.

Uma perspectiva multidisciplinar da tradução no Brasil. In: MARTINS, M. A. P. Tradução e multidisciplinariedade. Rio de Janeiro: Lucerna, 1999. p. 96-104.

ZILBERMAN, Regina. O Resumo de História Literária, de Ferdinand Denis: história da literatura enquanto campo de investigação. Veredas, v. 19. p. 121-144, 2013. Disponível em: <https://digitalisdsp.uc.pt/bitstream/10316.2/34566/1/Veredas19_artigo8.pdf?ln=pt-pt>. Acesso em 
REIS - Impactos da tradução escrita no Brasil do século XIX

8 de junho de 2015. 